\title{
Brain injury with systemic inflammation in newborns with congenital heart disease undergoing heart surgery
}

\author{
ROSSITZA P. PIRONKOVA ${ }^{1,8}$, JOSEPH GIAMELLI $^{1,9}$, HOWARD SEIDEN $^{1,10}$, VINCENT A. PARNELL ${ }^{2}$, \\ DOROTA GRUBER ${ }^{1,3}$, CRISTINA P. SISON ${ }^{4,5}$, CZESLAWA KOWAL $^{6}$ and KAIE OJAMAA ${ }^{1,5,7}$ \\ Divisions of ${ }^{1}$ Pediatric Cardiology and ${ }^{2}$ Pediatric Cardiothoracic Surgery, Department of Pediatrics, \\ Cohen Children's Medical Center of New York at Northwell Health, New Hyde Park, NY 11040; ${ }^{3}$ Department of Pediatrics, \\ Hofstra Northwell School of Medicine, Hempstead, NY 11549; ${ }^{4}$ Biostatistics Unit, \\ The Feinstein Institute for Medical Research, Northwell Health, Manhasset, NY 11030; \\ ${ }^{5}$ Department of Molecular Medicine, Hofstra Northwell School of Medicine, Hempstead, NY 11549; Centers for \\ ${ }^{6}$ Musculoskeletal and Autoimmune Diseases, and ${ }^{7}$ Immunology and Inflammation, \\ The Feinstein Institute for Medical Research, Northwell Health, Manhasset, NY 11030, USA
}

Received November 1, 2016; Accepted January 13, 2017

DOI: $10.3892 /$ etm.2017.4493

\begin{abstract}
The potential role of systemic inflammation on brain injury in newborns with congenital heart disease (CHD) was assessed by measuring levels of central nervous system (CNS)-derived proteins in serum prior to and following cardiac surgery. A total of 23 newborns (gestational age, $39 \pm 1$ weeks) with a diagnosis of CHD that required cardiac surgery with cardiopulmonary bypass (CPB) were enrolled in the current study. Serum samples were collected immediately prior to surgery and 2, 24 and $48 \mathrm{~h}$ following CPB, and serum levels of phosphorylated neurofilament-heavy subunit (pNF-H), neuron-specific enolase (NSE) and S100B were analyzed. Systemic inflammation was assessed by measuring serum concentrations of complement $\mathrm{C} 5 \mathrm{a}$ and complement sC5b9, and the following cytokines: Interleukin (IL)-1 $\beta$, IL-6, IL-8, IL-10, IL12p70, interferon $\gamma$ and tumor necrosis factor (TNF)- $\alpha$. Analysis of cord blood from normal term deliveries $(n=26)$ provided surrogate normative values for newborns. pNF-H and S100B were 2.4- to 2.8-fold higher $(\mathrm{P}<0.0001)$ in patient sera than in cord blood prior to surgery and remained elevated following CPB. Pre-surgical serum pNF-H and S100B levels directly correlated with interleukin (IL)-12p70
\end{abstract}

Correspondence to: Dr Kaie Ojamaa, Center for Immunology and Inflammation, The Feinstein Institute for Medical Research, 350 Community Drive, Northwell Health, Manhasset, NY 11030, USA

E-mail:kojamaa@northwell.edu

Present addresses: ${ }^{8}$ Pediatric Cardiology, Bloomfield Hills, MI 48304; ${ }^{9}$ Department of Pediatrics, New York Medical College, Valhalla, NY 10595; ${ }^{10}$ Department of Pediatrics, Icahn School of Medicine at Mount Sinai, New York, NY 10029, USA

Key words: neonates, phosphorylated neurofilament heavy chain, neuron specific enolase, S100B, cytokines, cardiopulmonary bypass $(\rho=0.442, \mathrm{P}<0.05)$. pNF-H was inversely correlated with arterial $\mathrm{pO}_{2}$ prior to surgery $(\rho=-0.493, \mathrm{P}=0.01)$ and directly correlated with arterial $\mathrm{pCO}_{2}$ post-CPB $(\rho=0.426, \mathrm{P}<0.05)$, suggesting that tissue hypoxia and inflammation contribute to blood brain barrier (BBB) dysfunction and neuronal injury. Serum IL12p70, IL-6, IL-8, IL-10 and TNF- $\alpha$ levels were significantly higher in patients than in normal cord blood and levels of these cytokines increased following CPB $(\mathrm{P}<0.001)$. Activation of complement was observed in all patients prior to surgery, and serum $\mathrm{C} 5 \mathrm{a}$ and $\mathrm{sC} 5 \mathrm{~b} 9$ remained elevated up to 48 h post-surgery. Furthermore, they were correlated $(\mathrm{P}<0.05)$ with low arterial $\mathrm{pO}_{2}$, high $\mathrm{pCO}_{2}$ and elevated arterial pressure in the postoperative period. Length of mechanical ventilation was associated directly with post-surgery serum IL-12p70 and IL-8 concentrations $(\mathrm{P}<0.05)$. Elevated serum concentrations of pNF-H and S100B in neonates with CHD suggest BBB dysfunction and CNS injury, with concurrent hypoxemia and an activated inflammatory response potentiating this effect.

\section{Introduction}

Approximately 8 in 1,000 live births are diagnosed with a congenital heart defect (1) and many require surgical intervention to ensure survival beyond the neonatal period. Recent advances in medical management, transcatheter intervention, surgical procedures and cardiopulmonary bypass, have significantly increased the survival rate of such children. Up to $50 \%$ of children with congenital heart disease (CHD) experience neurodevelopmental and behavioral problems including seizures, cognitive impairment, delays in speech, language, visual-motor and visual-spatial skills, attention deficit/hyperactivity disorder and learning disabilities (2-5).

The etiology of the neurobehavioral problems in children with CHD is complex, with contributions of innate factors including genotype that cannot be modified and acquired factors that potentially may be (6). These acquired factors are secondary to chronic and acute hypoxia, hypoperfusion, 
hematocrit, reperfusion injury, and surgery with cardiopulmonary bypass and cross-clamp, and have a cumulative effect $(7,8)$. The developing fetus with congenital heart defects may be exposed to hypoxia and abnormal cerebral perfusion in utero and these insults on the brain may continue during the neonatal period as a result of the failing heart $(9,10)$. The mechanisms of brain injury are poorly understood but may involve multiple causative factors including maternal infection, inflammation, hypoxia and hypoperfusion, as observed in the development of periventricular leukomalacia (PVL), characterized by cerebral white matter damage (11-13). PVL has been documented by brain magnetic resonance imaging (MRI) in $16 \%$ of children with congenital heart disease and this incidence increases to $50 \%$ in children following cardiac surgery with cardiopulmonary bypass (CPB) (14). The duration of $\mathrm{CPB}$, complexity of the anatomical defect and surgical repair, and the occurrence of cyanosis contribute to the postoperative systemic inflammatory response. This involves activated complements and lymphocytes, monocytes/macrophages, endothelial cells and myocytes expressing cytokines, such as tumor necrosis factor (TNF)- $\alpha$ and interleukins (ILs) (15-20). Postoperative systemic inflammatory response syndrome is a complication occurring in pediatric patients, particularly neonates undergoing corrective or palliative heart surgery and remains a challenge during the postoperative management of these patients (21-25). Inflammation during early brain development has been implicated in white matter damage and has been associated with cerebral palsy, autism and neuropsychological disorders (26-29). In experimental models, TNF- $\alpha$ induced myelin degeneration and oligodendrocyte apoptosis, and transgenic animals overexpressing TNF- $\alpha$ in the CNS exhibited demyelination and vacuolization $(30,31)$. White matter injury is a complication of neonatal cardiac surgery and may occur in response to systemic inflammation; however, this association remains unclear and may be of relevance regarding patients undergoing highly complex cardiac surgeries $(32,33)$.

The blood-brain and blood-cerebrospinal fluid (CSF) barriers restrict the passage of proteins into and out of the brain. Research on the blood-brain barrier (BBB) in experimental models has demonstrated that prolonged systemic inflammation in the early post-natal period leads to a transient increase in the permeability of blood vessels in the brain to serum proteins (34). Similar to that observed with ischemic or traumatic brain injury, it has been postulated that cardiopulmonary bypass with concomitant inflammation and activation of complements can lead to loss of integrity of the $\mathrm{BBB}$ and blood-CSF barrier (35-38).

Previous studies have determined that there is an association between the severity of the inflammatory response to heart surgery and an increased need for medical intervention or length of stay at hospitals (20,21,39-43). The current study hypothesized that newborns with CHD and in whom circulating pro-inflammatory mediators and complements were elevated, would have measureable concentrations of CNS-derived proteins, indicative of a compromised BBB and CNS injury. Serum markers of brain injury (43) include the high molecular weight $(200 \mathrm{kDa})$ neurofilament protein (NF-H) that is abundant in neurons and concentrated in axons. The highly phosphorylated form of NF (pNF-H) is resistant to proteolysis and when released from damaged axons remains largely intact; thus, its presence in the blood is indicative of neuronal damage $(44,45)$. Other biomarkers measured included a brain-specific isoform of enolase known as neuron specific enolase (NSE) (46) and S100, a $20 \mathrm{kDa}$ protein belonging to the S100/calmodulin/troponin C superfamily of calcium-binding proteins that forms heterodimers (S100A1B) and homodimers (S100BB) in CNS glial cells and peripheral Schwann cells $(47,48)$.

\section{Patients and methods}

Patient demographics and diagnostic classifications. The current prospective study conducted at the Cohen Children's Medical Center of New York at Northwell Health (Manhasset, NY, USA) was approved by the Northwell Health Institutional Review Board and conducted in accordance with the Declaration of Helsinki. Written informed consent was obtained from parents on admission of patients to the hospital. A total of 23 patients with congenital heart disease requiring surgical repair with cardiopulmonary bypass were enrolled in the present study between January 2009 and August 2010. Full patient demographics are listed in Table I. The lesions consisted of hypoplastic left heart syndrome $(n=8)$, transposition of the great arteries $(n=5)$, co-arctation of the aorta $(n=3)$, tricuspid atresia/pulmonary atresia $(n=1)$, truncus arteriosus communis $(n=1)$, aortopulmonary window $(n=1)$, endocardial cushion defect $(n=1)$, ventricular septal defect $(n=1)$, anomalous right pulmonary artery $(n=1)$ and total anomalous pulmonary venous connection $(n=1)$. Two patients harbored known chromosomal abnormalities, including one with DiGeorge syndrome (22q11 deletion). Criteria for exclusion were body weight $<1,600$ grams, patent ductus arteriosus ligations, heart surgery without $\mathrm{CPB}$, newborns of mothers with autoimmune disease and suspected congenital or postnatal infections.

Surgery, anesthesia and postoperative care. The conduction of surgical procedures including cardiopulmonary bypass and anesthesia followed our institutional standard practices. Sixteen of the 23 patients underwent CPB with deep hypothermic circulatory arrest with an average circulatory arrest time of $20 \pm 16 \mathrm{~min}$. Eleven of these 16 patients were treated by ice cooling of the head. Twenty-one patients required blood pressure medication intra-operatively and all patients received methylprednisolone. Postoperative patient management in the pediatric intensive care unit (PICU) followed the standard institutional protocol. Decisions regarding the medical management of each patient were based on clinical assessment made by attending PICU physicians who were unaware of the study protocol and analysis.

Clinical data acquisition and sample collection. Patient clinical data were recorded, including pre-operative variables such as birth weight, gestational age, APGAR score at birth, head circumference, abnormal chromosomal findings, abnormal head ultrasound findings, need for respiratory support including intubation and fraction of inspired oxygen $\left(\mathrm{FiO}_{2}\right)$ requirement, pre-operative systemic saturation, arterial $\mathrm{pO}_{2}$ and $\mathrm{pCO}_{2}$, lowest pre-operative hematocrit, degree of acidosis, lactate levels, mean arterial pressures, urine output, presence of infection, presence of seizures, administration 
of vaccines or Rhogam, need for blood transfusion, need of prostin infusion or inotropes, or balloon atrial septostomy. Intra-operative data were recorded, including weight and age at perfusion, length of cardiopulmonary bypass and aortic cross-clamp time, administration of intra-op steroids and degree of cooling. Postoperative variables were also measured and included presence of arrhythmia, medication including inotropes and diuretics, mean arterial blood pressure (MAP), degree of acidosis, blood lactate levels, hematocrit, $\mathrm{pO}_{2}$ and $\mathrm{pCO}_{2}, \mathrm{FiO}_{2}$ requirement, duration of mechanical ventilation, duration of PICU care and hospitalization, systemic oxygen saturation at discharge and any neurological findings such as seizures, neurodevelopmental risk evaluation score or brain imaging results. Brain imaging protocols included brain ultrasound, computed tomography, electroencephalogram (EEG) or MRI during routine postoperative care of the patient.

Blood samples from patients were drawn from central intravenous catheters preoperatively and 2, 24 and $48 \mathrm{~h}$ following CPB. Blood was allowed to clot at room temperature for $4 \mathrm{~h}$ and subsequently centrifuged at $1,000 \mathrm{x} \mathrm{g}$ for $15 \mathrm{~min}$ at room temperature. Serum was stored at $-70^{\circ} \mathrm{C}$ until analysis. Serum samples were also obtained from cord blood collected from 26 healthy term births that were donated to the Tissue Donation Program of Northwell Health but which were not used for stem cell collection due to insufficient cell counts. Data from these samples were used as normative newborn values.

Analyses of serum samples. Commercially available ELISA or EIA kits were used to measure serum concentrations of pNF-H (cat. no. RD191138300R; BioVendor LLC, Asheville, NC, USA), human NSE (cat. no. 0050; Alpha Diagnostic International, San Antonio, TX, USA), S-100B (cat. no. 708-85; Fujirebio Diagnostics, Inc., Göteborg, Sweden), C5a and sC5b-9 (cat. no. A021 \& A020; Quidel Corp., San Diego, CA, USA). The Meso Scale Discovery multiplex assay kit (cat. no. K15008C-2; MSD, Rockville, MD, USA) was used for simultaneous measurement of cytokines IL-6, IL-8, IL-12p70, IL-1 $\beta$, TNF- $\alpha$, interferon (INF)- $\gamma$, and IL-10 in each serum sample.

Immunoblot analysis. The specificity of the anti-pNF-H antibody used in the ELISA was verified via immunoblot analysis comparing mouse brain tissue with patient plasma samples. Murine brain lysate was prepared as previously described (49). For immunoblot analysis, serum samples (12 $\mu \mathrm{l})$ from 2 randomly selected patients were diluted in Laemmli buffer and separated by SDS-PAGE on $10 \%$ polyacrylamide gels, transferred to nitrocellulose membranes and incubated at $4^{\circ} \mathrm{C}$ overnight with monoclonal antibody against pNF-H (cat no. IMG-5018A-2; 1:1,000; Novus Biologicals, LLC, Littleton, CO, USA). Signal from horseradish peroxidase-conjugated secondary antibody (cat. no. 170-6516; 1:5,000; Bio-Rad Laboratories, Inc., Hercules, CA, USA) was developed using chemiluminescence reagent (Western Lightning Electrochemiluminescence Pro; cat. no. NEL120001EA; Perkin-Elmer, Inc., Waltham, MA, USA) and detected by exposure to X-ray film. A sample of murine brain lysate $(20 \mu \mathrm{g}$ protein) was used to positively identify the antibody reactive pNF-H protein band.
Statistical analysis. Comparisons among variables were made using one-way analysis of variance or Kruskal-Wallis test, as appropriate, for continuous-type measures and the $\chi^{2}$ or Fisher's exact test for categorical outcomes. Healthy controls were compared to patients using the Mann-Whitney test for continuous measures and the $\chi^{2}$ or Fisher's exact test for categorical outcomes. Spearman correlations were calculated to determine the strength of correlation between serum biomarkers. A mixed models approach to repeated measures analysis of variance was conducted to determine if the patterns of change across time with respect to each of the biomarker levels differed between groups. Bonferroni-like adjusted pairwise comparisons $(\mathrm{P}<0.01)$ were used post-hoc to determine which time points differed from one another. Statistical analysis was performed using SAS V9.3 (SAS Institute Inc., Cary, NC, USA).

\section{Results}

Study patients and perioperative data. Table I lists patient demographics, mean ( \pm standard deviation) and median values (min-max range) of specific pre-, intra- and postoperative physiological measures and outcome variables that were used for statistical analyses.

Role of cyanosis. A total of $70 \%(16 / 23)$ of patients were cyanotic prior to surgery, and they received surgery at a younger age compared with the seven acyanotic patients (5.9 \pm 3.2 vs. $11.4 \pm 6.4$ days, respectively). The cyanotic patients had significantly longer bypass times $(160 \pm 49$ vs. $100 \pm 15 \mathrm{~min}$; $\mathrm{P}=0.007)$ and total cross clamp times $(75 \pm 38$ vs. $40 \pm 17 \mathrm{~min}$; $\mathrm{P}=0.012)$ indicative of greater complexity of surgical cardiac repair. When patients prior to surgery were grouped as cyanotic or acyanotic, no statistically significant differences in serum biomarkers either prior to or following surgery were measured. Therefore, data from all patients were combined for the statistical analyses presented herein.

Brain biomarkers prior to and following cardiopulmonary bypass surgery. The presence of $\mathrm{pNF}-\mathrm{H}$ in the serum of newborns with CHD has not been previously reported. Therefore, the specificity of the detection antibody used in the ELISA assay was tested by immunoblot analysis of patient sera and mouse brain tissue known to express pNF-H. The antibody recognized both high- and medium-molecular weight NF proteins in mouse brain and a corresponding $200 \mathrm{kDa}$ protein in two patient serum samples, thus confirming its specificity (Fig. 1). pNF-H concentration in the pre-surgical samples of patients was 2.4-fold higher $(\mathrm{P}<0.0001)$ than that measured in cord blood from healthy term births (Table II). The concentration of $\mathrm{pNF}-\mathrm{H}$ in serum obtained $2 \mathrm{~h}$ after $\mathrm{CPB}$ was significantly reduced compared with pre-surgery $(\mathrm{P}<0.0001)$ but then accumulated during the subsequent period, reaching pre-surgical levels $48 \mathrm{~h}$ following CPB (Fig. 2). S100B, a protein expressed in glial cells, was also significantly higher in patient sera prior to surgery compared with normal cord blood $(\mathrm{P}<0.00001$; Table II) and increased significantly $2 \mathrm{~h}$ following $\mathrm{CPB}(\mathrm{P}<0.0001)$, further supporting potential CNS injury in these patients (Fig. 2). Both the rapid increase of S100B following CPB and subsequent rapid decrease in $24 \mathrm{~h}$ likely reflects its reported short 
Table I. Patient demographics and peri-operative variables.

\begin{tabular}{|c|c|c|c|}
\hline Variable & Mean $\pm \mathrm{SD}$ & Median & Min-max \\
\hline \multicolumn{4}{|l|}{ All patients $(n=23)$} \\
\hline Male \% (n) & $48(11)$ & & \\
\hline Gestational age, weeks & $39 \pm 1.4$ & 39.4 & $35.2-41.0$ \\
\hline Birth weight, kg & $3.235 \pm 0.410$ & 3.345 & $2.381-3.750$ \\
\hline Age at surgery, days & $7.6 \pm 5$ & 6.0 & $3-20$ \\
\hline Weight at surgery, kg & $3.2 \pm 0.4$ & 3.2 & $2.5-3.8$ \\
\hline Body mass index, $\mathrm{kg} / \mathrm{m}^{2}$ & $12.83 \pm 1.49$ & 12.57 & $10.97-18.12$ \\
\hline \multicolumn{4}{|l|}{ Pre-operative data } \\
\hline $\mathrm{SaO}_{2}(\%)$ & $87 \pm 11$ & 90 & $60-99$ \\
\hline $\mathrm{Hb}(\mathrm{g} / \mathrm{dl})$ & $12.5 \pm 2.5$ & 12.3 & $8.6-18.0$ \\
\hline $\mathrm{PaO}_{2}$ (median value, $\mathrm{mmHg}$ ) & $48 \pm 29$ & 40 & $25-154$ \\
\hline $\mathrm{PaCO}_{2}$ (highest value. $\mathrm{mmHg}$ ) & $50 \pm 22$ & 45 & $30-142$ \\
\hline $\mathrm{HCO}_{3}^{-}$(lowest value, $\mathrm{mEq} / \mathrm{l}$ ) & $20.3 \pm 4.3$ & 21.0 & $5-27$ \\
\hline $\mathrm{pH}$ & $7.27 \pm 0.16$ & 7.31 & $6.71-7.42$ \\
\hline Lactate (mg/dl) & $5.3 \pm 4.3$ & 3.7 & $1.4-21.0$ \\
\hline MAP (mmHg) & $48 \pm 4$ & 48 & $40-56$ \\
\hline \multicolumn{4}{|l|}{ Intra-operative data } \\
\hline Bypass time, min & $141 \pm 49$ & 139 & $44-240$ \\
\hline Cross-clamp time, $\min$ & $71 \pm 32$ & 72 & $21-14$ \\
\hline \multicolumn{4}{|l|}{ Postoperative data (within $48 \mathrm{~h}$ ) } \\
\hline $\mathrm{FiO}_{2}$ requirement & $0.48 \pm 0.18$ & 0.50 & $0.21-1.00$ \\
\hline Hb (lowest value, g/dl) & $11.3 \pm 1.7$ & 11.0 & $8.3-15.3$ \\
\hline $\mathrm{PaO}_{2}$ (lowest value, $\mathrm{mmHg}$ ) & $74 \pm 37$ & 64 & $29-160$ \\
\hline $\mathrm{PaCO}_{2}$ (median value, $\mathrm{mmHg}$ ) & $49 \pm 8$ & 50 & $35-60$ \\
\hline $\mathrm{pH}$ & $7.36 \pm 0.09$ & 7.37 & $7.07-7.50$ \\
\hline Lactate (highest value, $\mathrm{mg} / \mathrm{dl}$ ) & $8.0 \pm 6.6$ & 6.0 & $1.9-25.0$ \\
\hline $\mathrm{SaO}_{2}$ at discharge $\%$ & $90 \pm 10$ & 96 & $66-100$ \\
\hline MAP $(\mathrm{mmHg})$ & $52 \pm 5$ & 50 & $45-66$ \\
\hline Mechanical ventilation, days & $10.0 \pm 15.9$ & 5.0 & $1.0-69.0$ \\
\hline Intensive care unit stay, days & $13.3 \pm 14.5$ & 9.0 & $4.0-69.0$ \\
\hline Hospital stay, days & $20.8 \pm 13.5$ & 17.0 & $7.0-69.0$ \\
\hline
\end{tabular}

$\mathrm{SD}$, standard deviation; $\mathrm{Hb}$, hemoglobin; MAP, mean arterial blood pressure; $\mathrm{FiO}_{2}$, fraction of inspired oxygen.

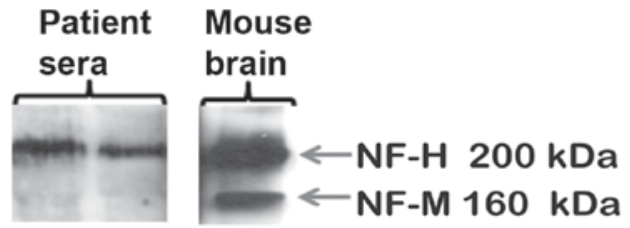

Figure 1. Immunoblot analysis of pNF-H in patient sera and mouse brain tissue. Molecular weight is indicated as kilodaltons (kDa). NF-H, neurofilament heavy chain subunit; NF-M, medium molecular weight subunit of neurofilament as identified in mouse brain.

half-life ( $\sim 60 \mathrm{~min})$. The amount of NSE in patient sera prior to surgery did not differ significantly from that in normal cord blood (Table II); however, it increased significantly $2 \mathrm{~h}$ post-CPB $(\mathrm{P}<0.0001)$ and then slowly decreased to pre-CPB levels over the subsequent $48 \mathrm{~h}$, reflecting a longer reported serum half-life of $\sim 30 \mathrm{~h}$ (Fig. 2).
Inflammation in neonates and response to surgery. Concentrations of cytokines, apart from INF- $\gamma$ and IL- $1 \beta$, were significantly lower in normal cord blood than in the sera of patients prior to surgery $(\mathrm{P}<0.05)$ (Table II). The responses of these inflammatory mediators to surgery are presented in Fig. 3. Serum levels of all ILs and INF- $\gamma$ peaked immediately following $\mathrm{CPB}(\mathrm{P}<0.01)$ and then decreased over the following 48 h (Fig. 3), although levels of IL-1 $\beta$ increased slightly but not significantly over 48 h post-CPB (data not shown). Serum TNF- $\alpha$ levels remained unchanged throughout the pre- and postoperative periods (Fig. 3). Complement activation, specifically the serum level of soluble C5b9, which potentially measures endothelial injury, was higher $(\mathrm{P}<0.0001)$ in patients prior to surgery than in normal cord blood (Table II). Serum C5a and sC5b9 concentrations increased progressively following surgery, with levels at $48 \mathrm{~h}$ being significantly higher than pre-surgical values ( $\mathrm{P}<0.01$; Fig. 4). 
Table II. Serum concentrations of cytokines and brain-derived biomarkers.

\begin{tabular}{lcc}
\hline Serum biomarker & $\begin{array}{c}\text { Normal cord blood } \\
\text { Mean } \pm \text { SD } \\
(\mathrm{n}=20)\end{array}$ & $\begin{array}{c}\text { CHD patients } \\
\text { pre-surgery } \\
\text { Mean } \pm \text { SD } \\
(\mathrm{n}=23)\end{array}$ \\
\hline $\mathrm{pNF}-\mathrm{H}(\mathrm{pg} / \mathrm{ml})$ & $136.8 \pm 53.9$ & $328.7 \pm 155.7^{\mathrm{d}}$ \\
S100B $(\mathrm{pg} / \mathrm{ml})$ & $126.3 \pm 113.6$ & $358.0 \pm 210.2^{\mathrm{d}}$ \\
NSE $(\mathrm{ng} / \mathrm{ml})$ & $20.27 \pm 9.93$ & $15.50 \pm 15.17$ \\
C5A $(\mathrm{ng} / \mathrm{ml})$ & $5.62 \pm 4.40$ & $12.87 \pm 8.40^{\mathrm{b}}$ \\
$\mathrm{sC} 5 \mathrm{~B} 9(\mathrm{ng} / \mathrm{ml})$ & $79.0 \pm 48.1$ & $652.2 \pm 491.1^{\mathrm{d}}$ \\
$\mathrm{INF}-\gamma(\mathrm{pg} / \mathrm{ml})$ & $0.18 \pm 0.13$ & $0.40 \pm 0.39$ \\
$\mathrm{IL}-10(\mathrm{pg} / \mathrm{ml})$ & $0.85 \pm 0.41$ & $6.61 \pm 7.03^{\mathrm{d}}$ \\
$\mathrm{IL}-12 \mathrm{p} 70(\mathrm{pg} / \mathrm{ml})$ & $0.15 \pm 0.26$ & $0.59 \pm 1.38^{\mathrm{a}}$ \\
$\mathrm{IL}-1 \beta(\mathrm{pg} / \mathrm{ml})$ & $0.66 \pm 1.12$ & $1.70 \pm 3.86$ \\
$\mathrm{IL}-6(\mathrm{pg} / \mathrm{ml})$ & $1.86 \pm 1.08$ & $11.01 \pm 17.99^{\mathrm{c}}$ \\
$\mathrm{IL}-8(\mathrm{pg} / \mathrm{ml})$ & $6.61 \pm 1.94$ & $36.49 \pm 48.62^{\mathrm{d}}$ \\
TNF- $\alpha(\mathrm{pg} / \mathrm{ml})$ & $4.43 \pm 1.12$ & $14.02 \pm 8.01^{\mathrm{d}}$ \\
\hline
\end{tabular}

Values are mean \pm SD of samples from cord blood of healthy term births and from patients with CHD obtained prior to heart surgery. $\mathrm{n}=$ number of patients. ${ }^{\mathrm{a}} \mathrm{P}<0.05 ;{ }^{\mathrm{b}} \mathrm{P}<0.01 ;{ }^{\mathrm{c}} \mathrm{P}<0.001 ;{ }^{\mathrm{d}} \mathrm{P}<0.00001$ vs. normal cord blood; TNF, tumor necrosis factor; IL, interleukin; INF, interferon; NSE, neuron specific enolase; CHD, congenital heart disease; SD, standard deviation.

Correlation between brain-derived biomarkers and inflammatory cytokines prior to surgery. The systemic inflammatory response to heart surgery with $\mathrm{CPB}$ in neonates has been well documented (15-21). However, immune function in neonates with CHD prior to heart surgery and its potential role on the clinical course of these patients is less clear. In the present study, Spearman correlation analysis demonstrated significant positive associations between the age of patients at surgery and pre-surgical serum levels of the cytokines $(\mathrm{P}<0.05$; Table III $)$. The age-dependent increases in serum IL-12p70, INF- $\gamma$ TNF- $\alpha$ and IL-10 may be indicative of immune activation of T helper (Th) 1 immune response in these neonates. By contrast, the levels of the interleukins IL-1 $\beta$, IL- 6 and IL- 8 were not correlated with patient age.

To support the hypothesis that inflammatory mediators serve a role in BBB permeability, it was observed that pre-surgical serum IL-12p70 concentrations correlated directly with levels of the brain proteins pNF-H and S100B ( $\mathrm{r}=0.442$, $\mathrm{P}<0.05$; Fig. 5). Fig. 5 presents individual patient values for these biomarkers and a linear regression line drawn between serum pNF-H and IL-12p70.

It was examined whether pre-operative blood pressure and/or inotropic support of patients correlated with inflammatory biomarkers. A total of 15 patients treated with diuretics had significantly higher serum TNF- $\alpha$, IL-10, IL12p70, IL1 $\beta$ and IL-6 levels compared with untreated patients $(\mathrm{P}<0.05$; Table IV). Seven of these 15 patients also received dopamine and 8 patients (4 receiving both diuretics and dopamine) had elevated blood creatinine levels compared with the normal range for neonates (data not shown), suggesting that patients
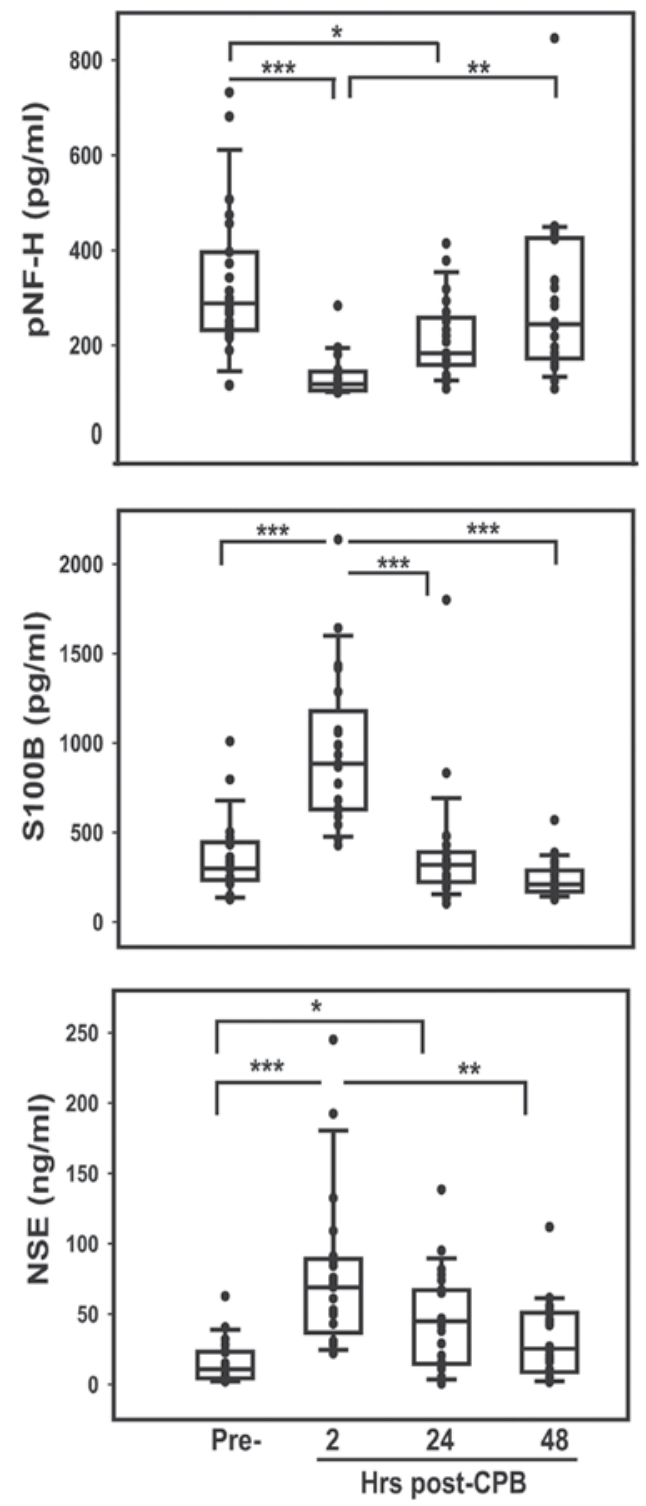

Figure 2. Concentration of CNS biomarkers in patient sera taken immediately prior to surgery (pre-) and at 2, 24 and $48 \mathrm{~h}$ post-CPB. Scatter plot represents individual patient data. Box plot: box boundaries indicates 25 th and 75 th percentile; line marks the median; whiskers indicate 10th and 90th percentiles. Statistical significance was determined by RM-ANOVA followed by Bonferroni post-hoc analysis for pairwise comparisons. ${ }^{*} \mathrm{P}<0.01$; ${ }^{* *} \mathrm{P}<0.001 ;{ }^{* * *} \mathrm{P}<0.0001$. CPB, NSE, neuron-specific enolase; $\mathrm{S} 100 \mathrm{~B}, \mathrm{~B}$ subunit of calcium-binding protein S100; pNF-H, phosphorylated neurofilament heavy chain; repeated measures-ANOVA, analysis of variance; CPB, cardiac surgery with cardiopulmonary bypass.

who were hemodynamically unstable exhibited an augmented inflammatory response. Furthermore, 12 patients requiring ventilator support had significantly lower serum concentrations of the anti-inflammatory cytokine IL-10, compared with those who were not mechanically ventilated $(\mathrm{P}<0.05$; Table IV). Of the other pre-operative variables recorded, arterial blood $\mathrm{pO}_{2}$ correlated inversely with serum pNF-H, suggesting a potential causal relationship between hypoxemia and increased CNS injury (Table V).

Postoperative outcomes and serum biomarkers. Postoperative outcome variables demonstrating statistically significant correlations with serum brain biomarkers, cytokines and 

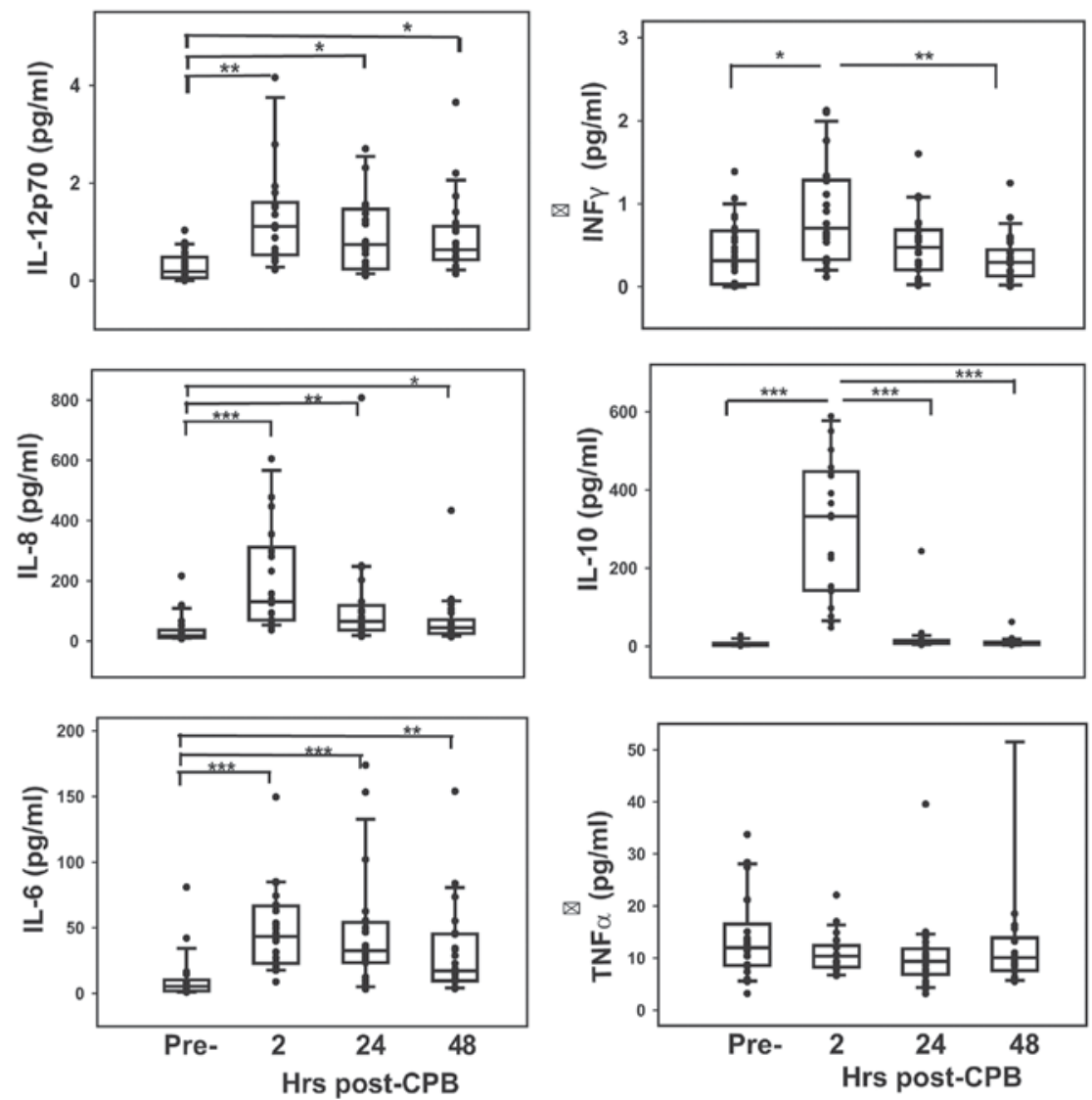

Figure 3. Concentration of cytokines in patient sera taken immediately prior to surgery (pre-) and 2, 24 and 48 h post-CPB. Scatter plot represents individual patient data. Box plot: box boundaries indicates 25th and 75th percentile; line marks the median; whiskers indicate 10th and 90th percentiles. Statistical significance was determined by $\mathrm{RM}-\mathrm{ANOVA}$ followed by Bonferroni post-hoc analysis for pairwise comparisons. ${ }^{*} \mathrm{P}<0.01$; ${ }^{* *} \mathrm{P}<0.001$; ${ }^{* * *} \mathrm{P}<0.0001$. $\mathrm{CPB}$, cardiac surgery with cardiopulmonary bypass; RM-ANOVA, analysis of variance; IL, interleukin; INF, interferon; TNF, tumor necrosis factor.
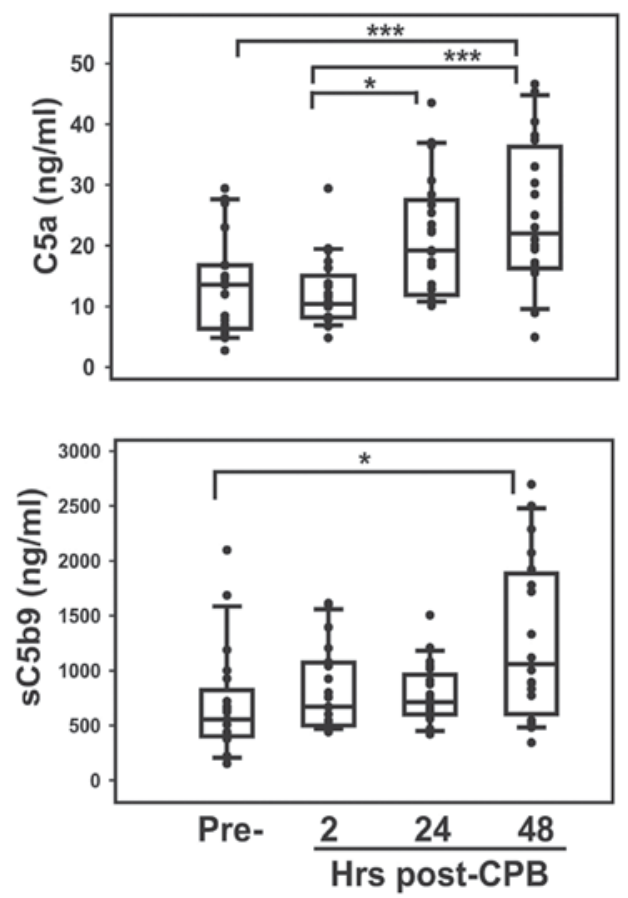

Figure 4. Concentration of complement in patient sera taken immediately prior to surgery and at 2, 24 and $48 \mathrm{~h}$ post-CPB. Scatter plot represents individual patient data. Box plot: box boundaries indicates 25 th and 75 th percentile; line marks the median; whiskers indicate 10th and 90th percentiles. Statistical significance was determined by RM-ANOVA followed by Bonferroni post-hoc analysis for pairwise comparisons. ${ }^{*} \mathrm{P}<0.01 ;{ }^{* * *} \mathrm{P}<0.0001$. complements are presented in Table V. Correlations were determined between physiological measurements recorded during the first or second $24 \mathrm{~h}$ period post-CPB and blood samples obtained at 24 or $48 \mathrm{~h}$. MAP during the first 2 days post-CPB correlated positively with serum TNF- $\alpha$ and C5a. Measurements indicative of tissue hypoxia including arterial blood gases $\left(\mathrm{pO}_{2}, \mathrm{pCO}_{2}\right)$ and lactate, and increased requirement for oxygen inhalation $\left(\mathrm{FiO}_{2}\right)$ correlated significantly with inflammatory responses and complement activation. Levels of the brain biomarkers pNF-H and NSE correlated directly with blood $\mathrm{pCO}_{2}$ and lactate, respectively (both $\mathrm{P}<0.05$ ) during the first 24 and $48 \mathrm{~h}$ post- $\mathrm{CPB}$, suggesting that hypoxia may have contributed to BBB permeability and release of these brain proteins. Serum levels of S100B and NSE, as well as IL-8 and IL-10, were inversely correlated with blood oxygen saturation at hospital discharge $(\mathrm{P}<0.01, \mathrm{P}<0.05, \mathrm{P}<0.01$ and $\mathrm{P}<0.01$, respectively) suggesting that systemic inflammation following surgery was an important determinant of clinical course (Table V). The postoperative duration of mechanical ventilation (length of intubation) was directly correlated with serum levels of IL-12p70 and IL-8 measured $48 \mathrm{~h}$ post-CPB (both $\mathrm{P}<0.05$; Table V).

Although only a small number of patients (six) without chromosomal abnormalities exhibited anomalies in brain imaging during their hospital course, they had significantly higher serum levels of IL-12p70 (1.21 \pm 0.58 vs. $0.77 \pm 0.86 \mathrm{pg} / \mathrm{ml}$, $\mathrm{P}<0.05)$ and NSE $(50.64 \pm 32.19$ vs. $23.52 \pm 20.86 \mathrm{ng} / \mathrm{ml}, \mathrm{P}<0.05)$ 
Table III. Correlations between serum biomarkers and patient age.

\begin{tabular}{lcccc}
\hline & TNF- $\alpha$ & INF- $\gamma$ & IL-10 & IL-12p70 \\
\hline $\begin{array}{l}\text { Age at blood } \\
\text { draw/surgery }\end{array}$ & $0.500^{\mathrm{a}}$ & $0.638^{\mathrm{c}}$ & $0.491^{\mathrm{a}}$ & $0.656^{\mathrm{c}}$ \\
IL-12p70 & $0.544^{\mathrm{b}}$ & $0.737^{\mathrm{d}}$ & $0.576^{\mathrm{b}}$ & - \\
IL-8 & $0.660^{\mathrm{c}}$ & $\mathrm{ns}$ & $\mathrm{ns}$ & $\mathrm{ns}$ \\
sC5b9 & $0.450^{\mathrm{a}}$ & $\mathrm{ns}$ & $\mathrm{ns}$ & $\mathrm{ns}$ \\
\hline
\end{tabular}

Correlations between biomarker concentrations in patient sera obtained immediately before surgery and patient age at surgery at the time of blood draw. Numbers are Spearman correlations $\rho$-values; ${ }^{\mathrm{a}} \mathrm{P}<0.05 ;{ }^{b} \mathrm{P}<0.01 ;{ }^{\mathrm{c}} \mathrm{P}<0.001 ;{ }^{\mathrm{d}} \mathrm{P}<0.0001$. ns, not statistically significant correlation; IL, interleukin; TNF tumor necrosis factor; INF, interferon.

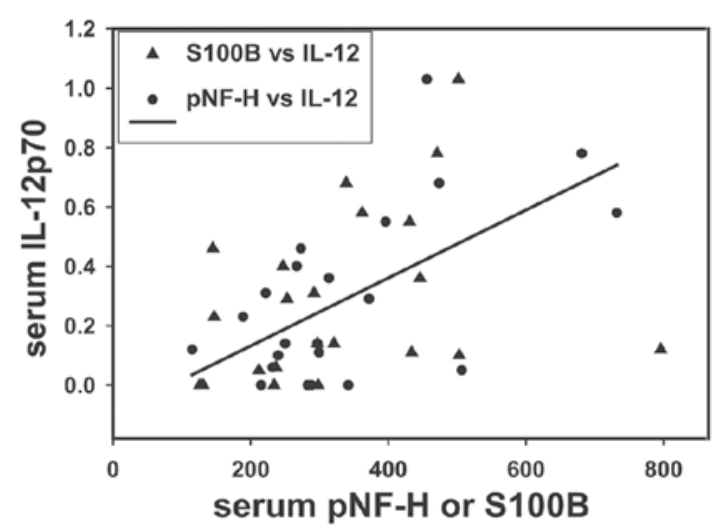

Figure 5. Spearman correlation analysis between brain biomarkers, pNF-H, S100B and cytokine IL-12p70 in patient sera obtained prior to surgery demonstrated similar correlation coefficients of $\rho=0.442$ and $\mathrm{P}<0.05$. The straight line represents the best-fit linear regression between $\mathrm{pNF}-\mathrm{H}$ and IL-12p70. Triangles or circles represent individual patient serum S100B or pNF-H values, respectively, plotted vs. serum IL-12p70. IL, interleukin pNF-H, phosphorylated neurofilament-heavy subunit.

following surgery compared with the 15 patients without any suspicion of CNS pathology or clinical findings.

\section{Discussion}

In the present study, it was hypothesized that newborns with CHD and specifically those with tissue hypoxia, experience systemic inflammation as a consequence of the disease, which results in dysfunction of the BBB and subsequent injury to the CNS as measured by the presence of circulating CNS-derived proteins. A number of studies have linked elevated levels of circulating pro-inflammatory cytokines, including TNF- $\alpha$ and IL-6 that are derived from peripheral immune cells or sites of organ/tissue injury, to BBB failure $(50,51)$. Evidence suggests that brain microvascular endothelial cell damage may occur due to cytokine-induced reactive oxidative species produced by NADPH oxidases or by altered function of endothelial junction proteins $(52,53)$ and that hypoxia-induced cytokine production may be an initiating event (54). Brain biomarkers, including pNF-H, S100B and NSE were detectable in patient serum prior to surgery and the concentrations of pNF-H and S100B were $\sim 2.5$-fold higher in patients than in normal cord blood. Both pNF-H and S100B levels were directly correlated with serum IL-12p70 and the correlation between pNF-H and IL-8 trended towards significance. These data support a potential causal link between pro-inflammatory mediators and BBB dysfunction with neuronal injury in these neonates. Furthermore, pre-operative arterial $\mathrm{pO}_{2}$ correlated inversely with serum pNF-H, while the strongest correlation with pre-operative arterial $\mathrm{pCO}_{2}$ was with TNF- $\alpha$, suggesting that hypoxia and acidosis in neonatal patients with CHD may be an initiating event for the peripheral inflammatory response with a direct effect on CNS injury. This conclusion is further supported by results obtained from the $24-48 \mathrm{~h}$ postoperative period, during which serum pNF-H correlated significantly with arterial $\mathrm{pCO}_{2}$, while NSE correlated directly with serum lactate. Furthermore, NSE and S100B were inversely associated with arterial oxygen saturation at discharge.

Modified ultrafiltration that allows for hemoconcentration and recovery of circuit blood following CPB, has been shown to remove certain inflammatory cytokines and components of the complement system from the circulation (55). Serum concentrations of IL-6, IL-10, TNF- $\alpha$ and C5b9 prior to and immediately following CPB in the present study are similar to those published in a study by Berdat et al (56) that demonstrated that various ultrafiltration methods were effective at removing such mediators to a varying extent. Despite ultrafiltration, levels of the inflammatory mediators NSE and S100B, increased significantly immediately following CPB, reflecting their release/secretion and accumulation. Serum concentration of pNF-H, a large $200 \mathrm{kDa}$ protein, decreased following CPB compared to pre-surgical levels, suggesting that it had been effectively removed by ultrafiltration. One explanation for these changes could be either volume expansion or hemoconcentration as a result of the CPB procedure. However, the results of the current study suggest that the temporal differences in serum concentrations of pNF-H, NSE and S100B possibly depended on their individual half-lives. The short half-life of S100B (90 min) predicted its rapid rise and fall immediately following CPB $(<24 \mathrm{~h})$, whereas the relatively longer half-life of NSE $(\sim 30 \mathrm{~h})$ was reflected in its slower decline with serum concentrations at $24 \mathrm{~h}$ remaining significantly higher than pre-surgery. By contrast, the stable hyperphosphorylated NF-H protein with a half-life $>3$ days, was slow to rise in serum and took $48 \mathrm{~h}$ to reach concentrations similar to pre-surgery. Previous studies have demonstrated that pNF is elevated in serum for weeks following spinal cord or mild brain injury and in children with febrile seizures $(45,57)$. Although the kinetics of these molecules in serum remain largely unknown, these data support the hypothesis that the BBB remains permeable in the initial $\mathrm{h}$ following CPB but begins to close within the first postoperative day. Abu-Sultaneh et al (48) demonstrated a significant correlation between peak serum S100B following $\mathrm{CPB}$ with cerebral oxygen desaturation during surgery, as measured by near-infrared spectroscopy. Furthermore, it has been demonstrated that cerebral oxygen saturation is correlated with neurodevelopmental outcomes and brain MRI at one year of age (58). While brain biomarkers, including S100B and NSE, have been studied in children in response to cardiac surgery with $\mathrm{CPB}$, to the best of our knowledge this study isthe 
Table IV. Effects of pre-operative treatments on serum cytokine concentrations.

\begin{tabular}{|c|c|c|c|c|c|c|}
\hline \multirow[b]{2}{*}{ Treatment variables } & \multirow[b]{2}{*}{$\mathrm{n}$} & \multicolumn{5}{|c|}{ Serum cytokines (pg/ml) } \\
\hline & & $\mathrm{TNF}-\alpha$ & IL-10 & IL-12p70 & IL- $1 \beta$ & IL-6 \\
\hline \multicolumn{7}{|l|}{ Ventilator support } \\
\hline$(+)$ & 12 & ns & $3.72 \pm 2.88^{\mathrm{a}}$ & ns & ns & ns \\
\hline$(-)$ & 10 & ns & $10.15 \pm 8.93$ & ns & ns & ns \\
\hline \multicolumn{7}{|l|}{ Diuretics } \\
\hline$(+)$ & 15 & $16.83 \pm 8.14^{\mathrm{a}}$ & $8.73 \pm 7.93^{\mathrm{a}}$ & $0.39 \pm 0.31^{\mathrm{a}}$ & $1.60 \pm 2.73^{\mathrm{a}}$ & $14.84 \pm 21.58^{\mathrm{a}}$ \\
\hline$(-)$ & 8 & $8.41 \pm 3.60$ & $2.99 \pm 2.65$ & $0.11 \pm 0.10$ & $0.30 \pm 0.22$ & $4.09 \pm 4.82$ \\
\hline
\end{tabular}

Table V. Correlations between pre- or postoperative physiologic measurements and serum biomarkers.

\begin{tabular}{|c|c|c|c|c|c|c|c|c|c|}
\hline \multirow[b]{2}{*}{ Variables } & \multicolumn{9}{|c|}{ Serum brain biomarkers, complement, cytokines } \\
\hline & $\mathrm{pNF}-\mathrm{H}$ & S100B & NSE & $\mathrm{C} 5 \mathrm{a}$ & sC5b9 & TNF- $\alpha$ & IL-10 & IL-12p70 & IL-8 \\
\hline \multicolumn{10}{|l|}{ PRE-OP } \\
\hline $\mathrm{pO}_{2}$ (median value on $\left.\mathrm{ABG}\right)$ & $-0.493^{\mathrm{a}}$ & ns & ns & ns & ns & ns & ns & ns & ns \\
\hline $\mathrm{pCO}_{2}$ (highest value on $\mathrm{ABG}$ ) & ns & ns & ns & ns & ns & $+0.448^{\mathrm{a}}$ & ns & ns & ns \\
\hline \multicolumn{10}{|l|}{ POSTOP } \\
\hline MAP (median daily value) & ns & ns & ns & $+0.551^{\mathrm{b}}$ & ns & $+0.407^{\mathrm{a}}$ & ns & ns & ns \\
\hline $\mathrm{pO}_{2}$ (lowest daily value $\mathrm{ABG}$ ) & $\mathrm{ns}$ & $\mathrm{ns}$ & ns & ns & $-0.520^{\mathrm{b}}$ & ns & $-0.437^{\mathrm{a}}$ & ns & $-0.430^{\mathrm{a}}$ \\
\hline $\mathrm{pCO}_{2}$ (median daily value $\mathrm{ABG}$ ) & $+0.426^{\mathrm{a}}$ & ns & ns & $+0.423^{\mathrm{a}}$ & ns & ns & $+0.449^{\mathrm{a}}$ & ns & ns \\
\hline Lactate (maximum daily value) & ns & ns & $+0.631^{\mathrm{a}}$ & ns & $-0.500^{\mathrm{a}}$ & ns & $+0.553^{\mathrm{b}}$ & $+0.727^{\mathrm{c}}$ & $+0.475^{\mathrm{a}}$ \\
\hline $\mathrm{FiO}_{2}$ requirement & ns & ns & ns & ns & ns & $+0.425^{\mathrm{a}}$ & $+0.483^{\mathrm{a}}$ & ns & ns \\
\hline $\mathrm{O}_{2}$ saturation at discharge & ns & $-0.584^{b}$ & $-0.489^{\mathrm{a}}$ & ns & $+0.663^{\mathrm{c}}$ & ns & $-0.611^{b}$ & ns & $-0.556^{\mathrm{b}}$ \\
\hline Length of intubation & ns & ns & ns & ns & ns & ns & ns & $+0.442^{\mathrm{a}}$ & $+0.445^{\mathrm{a}}$ \\
\hline
\end{tabular}

first to measure pNF-H in the serum of newborns with $\mathrm{CHD}$ undergoing open-heart surgery with CPB.

Newborns with complex CHD have an increased risk of white matter injury, reduced brain growth and delayed brain development $(6,59)$ and those requiring corrective surgeries with CPB during the neonatal period experience an inflammatory response $(2,13,14,21,60,61)$. Although inflammation during the perinatal period has been determined to affect brain development in the pre-term infant $(28,29)$, the significance of inflammation on the long-term neurocognitive development of children with CHD who have undergone surgical cardiac repair remains unclear and its significance is controversial $(7,33)$. Upon examination of various pre-operative treatments and postoperative physiological outcome measurements, it was determined that patients receiving diuretics and/or dopamine had significantly higher serum concentrations of many cytokines, which cannot be explained solely by changes in intravascular/extracellular fluid volumes. In the postoperative period, levels of IL-10 and IL-8 correlated with arterial hypoxemia and increased with blood lactate levels and inhaled $\mathrm{O}_{2}$ requirements. Other cytokines, including TNF- $\alpha$ and IL-12p70, similarly correlated with these post-surgical parameters but with varying strengths of association. Thus, taken together these data support an augmented systemic inflammatory response to tissue hypoxia and acidosis, with an increased need for mechanical ventilation with higher oxygen requirements in the postoperative period, suggesting that these neonates may be at higher risk of CNS injury.

In light of reports that activation of complement leads to loss of integrity of the BBB and blood-CSF barrier, the 
serum content of C5a was measured to assess activation of the complement system and serum $\mathrm{sC} 5 \mathrm{~b}-9$ to assess potential cellular damage mediated by complement. Activation of the complement system has been observed in intracranial inflammation following traumatic brain injury with upregulation of soluble terminal complement complex sC5b-9 in spinal cord fluid that correlated with degree of BBB dysfunction (36). C5a and $\mathrm{C} 3 \mathrm{a}$ are known leukocyte chemotactic factors that can induce the release of lysosomal enzymes and oxygen-derived free radicals, and can stimulate cytokine production and release (62). In the present study, serum C5a and sC5b9 were significantly higher in patients who had red blood cell transfusion prior to surgery and sC5b9 correlated directly with serum levels of TNF- $\alpha$ and IL-1 $\beta$. In the postoperative period C5a and sC5b9 correlated with various parameters indicative of arterial hypoxemia, elevated blood pressure and increased length of hospital stay. To the best of our knowledge, this is the first report demonstrating complement activation in this setting. Pagowska-Klimek et al (63) have recently reported that cardiac surgery with CPB activated the lectin pathway of complement activation and this response was significantly greater in pediatric patients presenting with post-bypass systemic inflammation. Further study is warranted in assessing the role of complement activation in brain injury in infants with CHD, particularly regarding novel therapeutic advances directed at the complement system to treat autoimmune diseases that may be repurposed for treatment of newborns with CHD (64-66).

It was observed that there was a significant correlation between patient age at surgery (between 3 and 20 days) and pre-surgical serum levels of TNF- $\alpha$, IL-12p70, INF- $\gamma$ and IL-10. The strongest correlation was between patient age at surgery and levels of IL-12 and INF- $\gamma$, which are Th1 cytokines. Newborns exhibit a bias toward a Th2 cell-dominated cytokine response, including the release of IL-4, IL-6 and IL-10; however, with increasing age and maturation of dendritic cells and their production of IL-12 in response to INF- $\gamma$, a shift to a Th1 cell response occurs $(67,68)$. The predominance of Th2 cytokine production in the fetus and neonate serves to dampen innate immune responses, protecting the newborn from Th1-induced affects $(69,70)$. The capacity of mononuclear cells to secrete a number of inflammatory cytokines increases with age from 2 months through one year to adulthood; however, monocytes from normal cord blood, which is essentially newborn blood, have increased capacity in response to pathogens to secrete TNF- $\alpha$, IL-6, IL-10 and INF- $\gamma$ (but not IL-12) at levels observed in adults $(71,72)$. Similarly, the observation that serum concentrations of TNF- $\alpha$, INF- $\gamma$ and IL-12p70 increased in neonates as they lived longer with their disease prior to heart surgery suggests that the production of Th1 cytokines was in response to disease-induced effects rather than normal maturation of immunity towards Th1 cell polarization. Gestational age and weight have been reported to be important determinants of the neonate's immune response to infection (73). In the current study, mean gestational age was 39 weeks and no neonates were small for their gestational age, suggesting that these newborns had the capacity to elicit an age-appropriate innate immune response. Therefore, the current study concludes that term newborns with congenital heart disease may be able to elicit an age-appropriate immune response; however, this response to their disease process may promote an excessive pro-inflammatory Th1 response potentially leading to end-organ damage, including increased permeability of the BBB and neuronal injury. New avenues of investigation, including studies examining the response of isolated peripheral blood mononuclear cells from neonates with CHD to various pathogenic and danger signals may advance understanding of innate immunity in this unique patient group and improve approaches to their medical care.

Limitations of the current study are the small sample size and absence of data from age-matched normal neonates aged between 3 and 30 days. Cord blood was analyzed from healthy term deliveries to provide surrogate normative newborn values. Although none of the study patients were small for gestational age or born pre-maturely, prospective collection of cord blood from these subjects would be preferable. A further limitation is the inclusion of congenital heart disease pathologies with varying degrees of severity and complexity. Despite these limitations, consistent immune responses were observed in this patient population, lending support to the significance of the results.

In summary, the results of the present study demonstrate that neonates with congenital heart disease requiring surgical repair/palliation during the first month of life have elevated serum levels of $\mathrm{pNF}-\mathrm{H}$, a CNS-derived axonal protein that suggests brain injury with loss of BBB integrity. Concentrations of complement and pro-inflammatory cytokines in the patients' serum were found to be higher than normal cord blood, and these biomarkers of inflammation were significantly correlated with pre- and post-operative measurements of tissue hypoxia/acidosis, and an increased need for mechanical ventilation with higher oxygen requirements, suggesting that these neonates may be at higher risk of CNS injury.

\section{Acknowledgements}

The present study was funded in part by the National Institutes of Health, National Center for Research Resources, The Feinstein Institute for Medical Research at Northwell Health (grant. no. M01RR018535).

\section{References}

1. Go AS, Mozaffarian D, Roger VL, Benjamin EJ, Berry JD, Blaha MJ, Dai S, Ford ES, Fox CS, Franco S, et al: Heart disease and stroke statistics-2014 update: A report from the american heart association. Circulation 129: e28-e292, 2014.

2. Miller SP, McQuillen PS, Hamrick S, Xu D, Glidden DV, Charlton N, Karl T, Azakie A, Ferriero DM, Barkovich AJ and Vigneron DB: Abnormal brain development in newborns with congenital heart disease. N Engl J Med 357: 1928-1938, 2007.

3. Sherlock RL, McQuillen PS and Miller SP; aCCENT: Preventing brain injury in newborns with congenital heart disease: Brain imaging and innovative trial designs. Stroke 40: 327-332, 2009.

4. Marino BS, Lipkin PH, Newburger JW, Peacock G, Gerdes M, Gaynor JW, Mussatto KA, Uzark K, Goldberg CS, Johnson WH Jr, et al: Neurodevelopmental outcomes in children with congenital heart disease: Evaluation and management: A scientific statement from the American heart association. Circulation 126: 1143-1172, 2012.

5. Gaynor JW, Stopp C, Wypij D, Andropoulos DB, Atallah J, Atz AM, Beca J, Donofrio MT, Duncan K, Ghanayem NS, et al: Neurodevelopmental outcomes after cardiac surgery in infancy. Pediatrics 135: 816-825, 2015.

6. Tabbutt S, Gaynor JW and Newburger JW: Neurodevelopmental outcomes after congenital heart surgery and strategies for improvement. Curr Opin Cardiol 27: 82-91, 2012. 
7. Hsia TY and Gruber PJ: Factors influencing neurologic outcome after neonatal cardiopulmonary bypass: What we can and cannot control. Ann Thorac Surg 81: S2381-S2388, 2006.

8. Gaynor JW, Wernovsky G, Jarvik GP, Bernbaum J, Gerdes M, Zackai E, Nord AS, Clancy RR, Nicolson SC and Spray TL: Patient characteristics are important determinants of neurodevelopmental outcome at one year of age after neonatal and infant cardiac surgery. J Thorac Cardiovasc Surg 133: 1344-1353, 1353 e1-3, 2007.

9. Licht DJ, Wang J, Silvestre DW, Nicolson SC, Montenegro LM, Wernovsky G, Tabbutt S, Durning SM, Shera DM, Gaynor JW, et al: Preoperative cerebral blood flow is diminished in neonates with severe congenital heart defects. J Thorac Cardiovasc Surg 128: 841-849, 2004.

10. Donofrio MT, Duplessis AJ and Limperopoulos C: Impact of congenital heart disease on fetal brain development and injury. Curr Opin Pediatr 23: 502-511, 2011.

11. Dammann O and Leviton A: Maternal intrauterine infection, cytokines, and brain damage in the preterm newborn. Pediatr Res 42: 1-8, 1997.

12. Kadhim H, Tabarki B, Verellen G, De Prez C, Rona AM and Sébire G: Inflammatory cytokines in the pathogenesis of periventricular leukomalacia. Neurology 56: 1278-1284, 2001.

13. Mahle WT, Tavani F, Zimmerman RA, Nicolson SC, Galli KK, Gaynor JW, Clancy RR, Montenegro LM, Spray TL, Chiavacci RM, et al: An MRI study of neurological injury before and after congenital heart surgery. Circulation 106 (12 Suppl 1): I109-I114, 2002.

14. Galli KK, Zimmerman RA, Jarvik GP, Wernovsky G, Kuypers MK, Clancy RR, Montenegro LM, Mahle WT, Newman MF, Saunders AM, et al: Periventricular leukomalacia is common after neonatal cardiac surgery. J Thorac Cardiovasc Surg 127: 692-704, 2004

15. Casey LC: Role of cytokines in the pathogenesis of cardiopulmonary-induced multisystem organ failure. Ann Thorac Surg 56 (5 Suppl): S92-S96, 1993.

16. Steinberg JB, Kapelanski DP, Olson JD and Weiler JM: Cytokine and complement levels in patients undergoing cardiopulmonary bypass. J Thorac Cardiovasc Surg 106: 1008-1016, 1993.

17. Gessler P, Pfenninger J, Pfammatter JP, Carrel T and Dahinden C: Inflammatory response of neutrophil granulocytes and monocytes after cardiopulmonary bypass in pediatric cardiac surgery. Intensive Care Med 28: 1786-1791, 2002.

18. Alcaraz AJ, Manzano L, Sancho L, Vigil MD, Esquivel F, Maroto E, Reyes E and Alvarez-Mon M: Different proinflammatory cytokine serum pattern in neonate patients undergoing open heart surgery. Relevance of IL-8. J Clin Immunol 25: 238-245, 2005.

19. Kozik DJ and Tweddell JS: Characterizing the inflammatory response to cardiopulmonary bypass in children. Ann Thorac Surg 81: S2347-S2354, 2006

20. Mahle WT, Matthews E, Kanter KR, Kogon BE, Hamrick SE and Strickland MJ: Inflammatory response after neonatal cardiac surgery and its relationship to clinical outcomes. Ann Thorac Surg 97: 950-966, 2014.

21. Allan CK, Newburger JW, McGrath E, Elder J, Psoinos C, Laussen PC, del Nido PJ, Wypij D and McGowan FX Jr: The relationship between inflammatory activation and clinical outcome after infant cardiopulmonary bypass. Anesth Analg 111: $1244-1251,2010$

22. Heying R, Wehage E, Schumacher K, Tassani P, Haas F, Lange R, Hess J and Seghaye MC: Dexamethasone pretreatment provides antiinflammatory and myocardial protection in neonatal arterial switch operation. Ann Thorac Surg 93: 869-876, 2012.

23. Kubicki R, Grohmann J, Siepe M, Benk C, Humburger F, Rensing-Ehl A and Stiller B: Early prediction of capillary leak syndrome in infants after cardiopulmonary bypass. Eur J Cardiothorac Surg 44: 275-281, 2013.

24. Graham EM, Atz AM, McHugh KE, Butts RJ, Baker NL, Stroud RE, Reeves ST, Bradley SM, McGowan FX Jr and Spinale FG: Preoperative steroid treatment does not improve markers of inflammation after cardiac surgery in neonates: Results from a randomized trial. J Thorac Cardiovasc Surg 147: 902-908, 2014

25. Floh AA, Nakada M, La Rotta G, Mah K, Herridge JE, Van Arsdell G and Schwartz SM: Systemic inflammation increases energy expenditure following pediatric cardiopulmonary bypass. Pediatr Crit Care Med 16: 343-351, 2015.

26. Patterson PH: Maternal infection: Window on neuroimmune interactions in fetal brain development and mental illness. Curr Opin Neurobiol 12: 115-118, 2002
27. Luciana M: Cognitive development in children born preterm Implications for theories of brain plasticity following early injury. Dev Psychopathol 15: 1017-1047, 2003.

28. O'Shea TM, Shah B, Allred EN, Fichorova RN, Kuban KC, Dammann O and Leviton A; ELGAN Study Investigators: Inflammation-initiating illnesses, inflammation-related proteins, and cognitive impairment in extremely preterm infants. Brain Behav Immun 29: 104-112, 2013

29. Hagberg H, Mallard C, Ferriero DM, Vannucci SJ, Levison SW, Vexler ZS and Gressens P: The role of inflammation in perinatal brain injury. Nat Rev Neurol 11: 192-208, 2015.

30. Selmaj KW and Raine CS: Tumor necrosis factor mediates myelin and oligodendrocyte damage in vitro. Ann Neurol 23: 339-346, 1988

31. Taupin V, Renno T, Bourbonnière L, Peterson AC, Rodriguez M and Owens T: Increased severity of experimental autoimmune encephalomyelitis, chronic macrophage/microglial reactivity, and demyelination in transgenic mice producing tumor necrosis factor-alpha in the central nervous system. Eur J Immunol 27: 905-913, 1997.

32. Li X, Robertson CM, Yu X, Cheypesh A, Dinu IA and Li J: Early postoperative systemic inflammatory response is an important determinant for adverse 2-year neurodevelopment-associated outcomes after the Norwood procedure. J Thorac Cardiovasc Surg 148: 202-206, 2014.

33. Desai NK, Hamrick SE, Strickland MJ, Matthews E, McMaster L and Mahle WT: White matter injury and the inflammatory response following neonatal cardiac surgery. Pediatr Cardiol 36: 942-949, 2015

34. Stolp HB, Dziegielewska KM, Ek CJ, Potter AM and Saunders NR: Long-term changes in blood-brain barrier permeability and white matter following prolonged systemic inflammation in early development in the rat. Eur J Neurosci 22: 2805-2816, 2005.

35. Chenoweth DE, Cooper SW, Hugli TE, Stewart RW, Blackstone EH and Kirklin JW: Complement activation during cardiopulmonary bypass: Evidence for generation of $\mathrm{C} 3 \mathrm{a}$ and C5a anaphylatoxins. N Engl J Med 304: 497-503, 1981.

36. Stahel PF, Morganti-Kossmann MC, Perez D, Redaelli C, Gloor B, Trentz $\mathrm{O}$ and Kossmann T: Intrathecal levels of complement-derived soluble membrane attack complex (sC5b-9) correlate with blood-brain barrier dysfunction in patients with traumatic brain injury. J Neurotrauma 18: 773-781, 2001.

37. Lassiter HA: The role of complement in neonatal hypoxic-ischemic cerebral injury. Clin Perinatol 31: 117-127, 2004.

38. Okamura T, Ishibashi N, Zurakowski D and Jonas RA: Cardiopulmonary bypass increases permeability of the blood-cerebrospinal fluid barrier. Ann Thorac Surg 89: 187-194, 2010.

39. Ashraf SS, Tian Y, Zacharrias S, Cowan D, Martin P and Watterson K: Effects of cardiopulmonary bypass on neonatal and paediatric inflammatory profiles. Eur J Cardiothorac Surg 12: 862-868, 1997.

40. McMahon CK, Klein I and Ojamaa K: Interleukin-6 and thyroid hormone metabolism in pediatric cardiac surgery patients. Thyroid 13: 301-304, 2003.

41. Madhok AB, Ojamaa K, Haridas V, Parnell VA, Pahwa S and Chowdhury D: Cytokine response in children undergoing surgery for congenital heart disease. Pediatr Cardiol 27: 408-813, 2006

42. Merchant S, Nadaraj S, Chowdhury D, Parnell VA, Sison C, Miller EJ and Ojamaa K: Macrophage migration inhibitory factor in pediatric patients undergoing surgery for congenital heart repair. Mol Med 14: 124-130, 2008.

43. Toman E, Harrisson S and Belli T: Biomarkers in traumatic brain injury: A review. J R Army Med Corps 162: 103-108, 2016.

44. Shaw G, Yang C, Ellis R, Anderson K, Parker Mickle J, Scheff S, Pike B, Anderson DK and Howland DR: Hyperphosphorylated neurofilament NF-H is a serum biomarker of axonal injury. Biochem Biophys Res Commun 336: 1268-1277, 2005.

45. Hayakawa K, Okazaki R, Ishii K, Ueno T, Izawa N, Tanaka Y, Toyooka S, Matsuoka N, Morioka K, Ohori Y, et al: Phosphorylated neurofilament subunit NF-H as a biomarker for evaluating the severity of spinal cord injury patients, a pilot study. Spinal Cord 50: 493-496, 2012.

46. Schmitt B, Bauersfeld U, Schmid ER, Tuchschmid P, Molinari L, Fanconi S and Bandtlow C: Serum and CSF levels of neuron-specific enolase (NSE) in cardiac surgery with cardiopulmonary bypass: A marker of brain injury? Brain Dev 20: 536-539, 1998. 
47. Lardner D, Davidson A, McKenzie I and Cochrane A: Delayed rises in serum S100B levels and adverse neurological outcome in infants and children undergoing cardiopulmonary bypass. Paediatr Anaesth 14: 495-500, 2004.

48. Abu-Sultaneh S, Hehir DA, Murkowski K, Ghanayem NS, Liedel J, Hoffmann RG, Cao Y, Mitchell ME, Jeromin A, Tweddell JS and Hoffman GM: Changes in cerebral oxygen saturation correlate with S100B in infants undergoing cardiac surgery with cardiopulmonary bypass. Pediatr Crit Care Med 15: 219-228, 2014.

49. Faust TW, Chang EH, Kowal C, Berlin R, Gazaryan IG, Bertini E, Zhang J, Sanchez-Guerrero J, Fragoso-Loyo HE, Volpe BT, et al: Neurotoxic lupus autoantibodies alter brain function through two distinct mechanisms. Proc Natl Acad Sci USA 107: 18569-18574, 2010.

50. Rochfort KD and Cummins PM: The blood-brain barrier endothelium: A target for pro-inflammatory cytokines. Biochem Soc Trans 43: 702-706, 2015.

51. Mir IN and Chalak LF: Serum biomarkers to evaluate the integrity of the neurovascular unit. Early Hum Dev 90: 707-711, 2014

52. Forster C, Burek M, Romero IA, Weksler B, Couraud PO and Drenckhahn D: Differential effects of hydrocortisone and TNFalpha on tight junction proteins in an in vitro model of the human blood-brain barrier. J Physiol 586: 1937-1949, 2008

53. Rochfort KD, Collins LE, Murphy RP and Cummins PM: Downregulation of blood-brain barrier phenotype by proinflammatory cytokines involves NADPH oxidase-dependent ROS generation: Consequences for interendothelial adherens and tight junctions. PLoS One 9: e101815, 2014

54. McAdams RM and Juul SE: The role of cytokines and inflammatory cells in perinatal brain injury. Neurol Res Int 2012: 561494, 2012.

55. Jönsson H, Johnsson P, Bäckström M, Alling C, Dautovic-Bergh C and Blomquist S: Controversial significance of early S100B levels after cardiac surgery. BMC Neurol 4: 24, 2004.

56. Berdat PA, Eichenberger E, Ebell J, Pfammatter JP, Pavlovic M, Zobrist C, Gygax E, Nydegger U and Carrel T: Elimination of proinflammatory cytokines in pediatric cardiac surgery: Analysis of ultrafiltration method and filter type. J Thorac Cardiovasc Surg 127: 1688-1696, 2004

57. Matsushige T, Inoue H, Fukunaga S, Hasegawa S, Okuda M and Ichiyama T: Serum neurofilament concentrations in children with prolonged febrile seizures. J Neurol Sci 321: 39-42, 2012.

58. Kussman BD, Wypij D, Laussen PC, Soul JS, Bellinger DC, DiNardo JA, Robertson R, Pigula FA, Jonas RA and Newburger JW: Relationship of intraoperative cerebral oxygen saturation to neurodevelopmental outcome and brain magnetic resonance imaging at 1 year of age in infants undergoing biventricular repair. Circulation 122: 245-254, 2010.

59. von Rhein M, Buchmann A, Hagmann C, Dave H, Bernet V, Scheer I, Knirsch W and Latal B; Heart and Brain Research Group: Severe congenital heart defects are associated with global reduction of neonatal brain volumes. J Pediatr 167: 1259-1263. e1, 2015.
60. Licht DJ, Shera DM, Clancy RR, Wernovsky G, Montenegro LM, Nicolson SC, Zimmerman RA, Spray TL, Gaynor JW and Vossough A: Brain maturation is delayed in infants with complex congenital heart defects. J Thorac Cardiovasc Surg 137: 529-537, 2009.

61. Ortinau C, Beca J, Lambeth J, Ferdman B, Alexopoulos D, Shimony JS, Wallendorf M, Neil J and Inder T: Regional alterations in cerebral growth exist preoperatively in infants with congenital heart disease. J Thorac Cardiovasc Surg 143: 1264-1270, 2012.

62. Barnum SR: Complement: A primer for the coming therapeutic revolution. Pharmacol Ther: Dec 1, 2016 (Epub ahead of print).

63. Pagowska-Klimek I, Swierzko AS, Michalski M, Glowacka E, Szala-Poździej A, Sokolowska A, Moll M, Krajewski WR, Romak J and Cedzyński M: Activation of the lectin pathway of complement by cardiopulmonary bypass contributes to the development of systemic inflammatory response syndrome after paediatric cardiac surgery. Clin Exp Immunol 184: 257-263, 2016.

64. Holers VM, Tomlinson S, Kulik L, Atkinson C, Rohrer B Banda $\mathrm{N}$ and Thurman JM: New therapeutic and diagnostic opportunities for injured tissue-specific targeting of complement inhibitors and imaging modalities. Semin Immunol 28: 260-267, 2016.

65. Zuercher AW, Spirig R, Baz Morelli A and Käsermann F: IVIG in autoimmune disease-Potential next generation biologics. Autoimmun Rev 15: 781-785, 2016.

66. Kolev MV, Tediose T, Sivasankar B, Harris CL, Thome J, Morgan BP and Donev RM: Upregulating CD59: A new strategy for protection of neurons from complement-mediated degeneration. Pharmacogenomics J 10: 12-19, 2010.

67. Zaghouani H, Hoeman CM and Adkins B: Neonatal immunity: Faulty T-helpers and the shortcomings of dendritic cells. Trends Immunol 30: 585-591, 2009.

68. Diesner SC,Förster-Waldl E, Olivera A,Pollak A, Jensen-Jarolim E and Untersmayr E: Perspectives on immunomodulation early in life. Pediatr Allergy Immunol 23: 210-223, 2012.

69. Marodi L: Innate cellular immune responses in newborns. Clin Immunol 118: 137-144, 2006.

70. Levy O and Wynn JL: A prime time for trained immunity: Innate immune memory in newborns and infants. Neonatology 105: 136-141, 2014.

71. Yerkovich ST, Wikström ME, Suriyaarachchi D, Prescott SL, Upham JW and Holt PG: Postnatal development of monocyte cytokine responses to bacterial lipopolysaccharide. Pediatr Res 62: 547-552, 2007.

72. Upham JW, Lee PT, Holt BJ, Heaton T, Prescott SL, Sharp MJ, Sly PD and Holt PG: Development of interleukin-12-producing capacity throughout childhood. Infect Immun 70: 6583-6585, 2002.

73. Strunk T, Currie A, Richmond P, Simmer K and Burgner D: Innate immunity in human newborn infants: Prematurity means more than immaturity. J Matern Fetal Neonatal Med 24: 25-31, 2011. 